\title{
Poéticas del Renacimiento. Reflexiones acerca de la cultura en Inglaterra durante los reinados de Isabel I y Jacobo I
}

\author{
Lucas Margarit (comp.), introducción de Lucas Margarit.
}

Buenos Aires: Editores Argentinos hnos., 2021; 369 pp.

ISBN 978-987-47882-1-4.

Jesica D. Lenga

Facultad de Filosofía y Letras, Universidad de Buenos Aires

Instituto de Filología y Literaturas Hispánicas "Dr. Amado Alonso".

Poéticas del Renacimiento. Reflexiones acerca de la cultura en Inglaterra durante los reinados de Isabel Iy Jacobo I recopila una serie de textos que funcionaron como poéticas o defensas de la poesía, publicados en Inglaterra entre 1579 y 1686 . Surgido en el marco del proyecto Ubacyt de título homónimo dirigido por el editor y compilador del volumen, Lucas Margarit, este libro no solo ofrece a los lectores hispanohablantes un conjunto de documentos que no habían sido traducidos al español anteriormente, sino que, además, cada uno de los textos está antecedido por una esmerada introducción a cargo de los traductores: Lucas Margarit, Cecilia Lasa, Elina Montes, María Inés Castagnino, Marcelo Lara, Mariano Vilar, Ezequiel Rivas y Noelia Fernández (según el orden de aparición).

La elección de las artes poéticas como vía de acercamiento al Renacimiento no es casual, este género ocupó un lugar protagónico en la producción teórica del período e hizo manifiesta, según el propio Margarit, la necesidad de los autores renacentistas por establecer un orden sistemático a nivel de la lengua, a nivel político y social en un momento de transformaciones profundas. Margarit también afirma en el prefacio del libro que cada poética constituye una manera de ver el mundo y expresa preocupaciones relacionadas con otros campos del saber y el poder. Los textos que componen el corpus indagan diversos aspectos de la realidad que van desde la importación de prácticas culturales foráneas o las conductas del cortesano ideal, hasta el debate por el nacionalismo y el lugar de Inglaterra en el mundo, así, estos ejercicios tempranos de la crítica literaria le permiten al lector comprender al hombre isabelino y su contexto intelectual.
En relación a este último aspecto, cobran gran relevancia los capítulos introductorios con los que cada traductor presenta su trabajo: en ellos se contextualiza históricamente a los autores y se describen las circunstancias que habilitaron el surgimiento de nuevas cosmovisiones estéticas en la corte isabelina. De esta forma, los documentos seleccionados cobran vida para público lector actual que, sin contar con estas introducciones, no podría captar plenamente el valor innovador de los mismos.

Por otro lado, gran parte de los textos antologados nos confrontan con un modo de abordar la literatura como objeto de estudio que al lector actual le resulta ajeno, como lo es el estilo polémico y panfletario de algunos prólogos, manifiestos o defensas recopilados, que nada tienen que ver con las formas de la escritura académica y cientificista de la crítica literaria contemporánea. Así, aproximarse hoy a esta retórica tan diferente le sirve al lector para desnaturalizar prácticas académicas y modos de concebir la producción intelectual en general. En ese sentido, Poéticas del Renacimiento se torna interesante, incluso para el público no especializado en cuestiones literarias.

El carácter dialógico, característico de los textos isabelinos se percibe claramente en el corpus seleccionado. Los autores se valen de la reelaboración o la confrontación de las ideas de sus antecesores como una estrategia retórica para desarrollar su punto de vista, estableciéndose así un complejo dialogo entre los nueve textos que componen el libro. 
A propósito de esto, una de las contiendas más interesantes que propone el libro es el que se establece en "In Defence of Poetry" (Thomas Lodge, 1579), traducido por Cecilia Lasa.

Lodge escribe su defensa de la poesía en un intento por refutar la diatriba contra el teatro que hace Stephen Gosson en The Schoole of Abuse. Sin embargo, para Lasa, este es un texto que a la vez que refuta y polemiza, procura configurar un nuevo modelo del lector. Si Gosson cuestiona al teatro desde una perspectiva moral y condena toda lectura que no tuviera un mensaje didáctico transparente, Lodge se propone formar a este nuevo público lector que surgía gracias a la expansión de la imprenta en la especificidad del lenguaje artístico, que construye sentidos a través de la sugerencia y la indeterminación. Lodge oculta detrás de la controversia con Gosson un manifiesto acerca de los modos de leer y demanda la aparición de un lector especializado en el discurso literario.

Poéticas del Renacimiento también nos permite acceder al debate alrededor de la cuestión de la lengua. En "The Art of English Poesy" (1589), traducido por María Inés Castagnino, Puttenham auspicia al inglés como lengua literaria por derecho propio y postula que puede existir un arte vernáculo, tal como existió el clásico, de la misma talla y categoría. Su empresa de adaptar las reglas de la composición poética clásica al inglés constituye en realidad un esfuerzo por prestigiarlo como lengua de la alta literatura.

Este afán por dotar al idioma propio de una serie de recursos discursivos y figuras retóricas que lo eleven al nivel de las lenguas clásicas reaparece en varios de los textos recopilados en el libro. Henry Peacham, por ejemplo, se propone en "The Garden of Eloquence" (1593)- traducción de Mariano Vilararmar uno de los primeros manuales de retórica en lengua inglesa. Este libro demuestra una voluntad democratizadora, ya que pone a disposición de oradores y autores que no accedían a los textos en latín, una serie de herramientas discursivas para desenvolverse en el ámbito político, religioso y literario.

De la dicotomía entre lo clásico y lo vernáculo se desprende uno de los asuntos más polémicos representados en el libro: el uso de la rima y la versificación. Margarit traduce "Observation in the Art of English Poesy" (1602) de Thomas Campion. Campion formula en su texto una enérgica embestida contra aquello que estaba deformando, e incluso, corrompiendo, en su opinión, la poesía inglesa: la rima. Habiendo escrito él mismo poemas en latín, Campion conmina a los poetas británicos a recuperar las formas de la poesía latina, brega por el uso de la musicalidad de la versificación clásica, al tiempo que se opone al empleo de la rima, procedimiento típico de la poesía popular y la tradición oral. Y en esto, que a simple vista parecería un debate puramente técnico y formal, subyace un posicionamiento político. Campion traza una frontera entre los poetas "instruidos" que lo sigan en su búsqueda de: "una forma verdadera de versificar en nuestra lengua" (cit. en Margarit, 2021, p.343) y quienes no obedezcan su programa, que quedan automáticamente del lado de los "no instruidos". Por supuesto que una postura tan controvertida como esta encuentra sus detractores, Samuel Daniel, por ejemplo, escribe una defensa de la rima en la que se posiciona a favor de las formas de la poesía popular.

Finalmente, en los textos de la antología se hace manifiesta la disputa en relación al tema de la traducción, la imitación y la originalidad en la creación artística. Algunos autores, como Harrington, se pronuncian a favor de la traducción como herramienta de innovación. En "A Brief Apology of Poetry" (1591)traducido por Marcelo Lara- Harrington se ampara en la definición de Sidney en su célebre Defensa de la poesía (1595), que la caracteriza como un "arte de la imitación" para avalar su labor como traductor del Orlando Furioso de Ariosto. El prefacio de Harrington da cuenta de la concepción humanista de la traducción, que, en lugar de limitarse a trasladar de una lengua a la otra palabra por palabra, pretende readaptar los discursos para que puedan funcionar en la sociedad receptora. El traductor ilumina los textos de una manera personal y subjetiva y, por eso, Harrington le otorga el status de autor. No obstante, esta perspectiva no es compartida por todos los autores de la antología, Puttenham respalda la figura del artista como un creador original, que no sigue las pautas de ningún modelo foráneo y lo distingue del traductor, que "es versificador, pero no poeta". 
En definitiva, Poéticas del Renacimiento demuestra al lector que lejos de estar anclada en la insularidad, Inglaterra participó de los debates planteados por el humanismo. Esta recopilación deconstruye la imagen naturalizada del Renacimiento como un fenómeno continental y particularmente italiano y presenta al investigador hispanohablante un panorama acabado de la producción intelectual y estética de los artistas renacentistas en Inglaterra, hasta ahora menos explorada en español. 